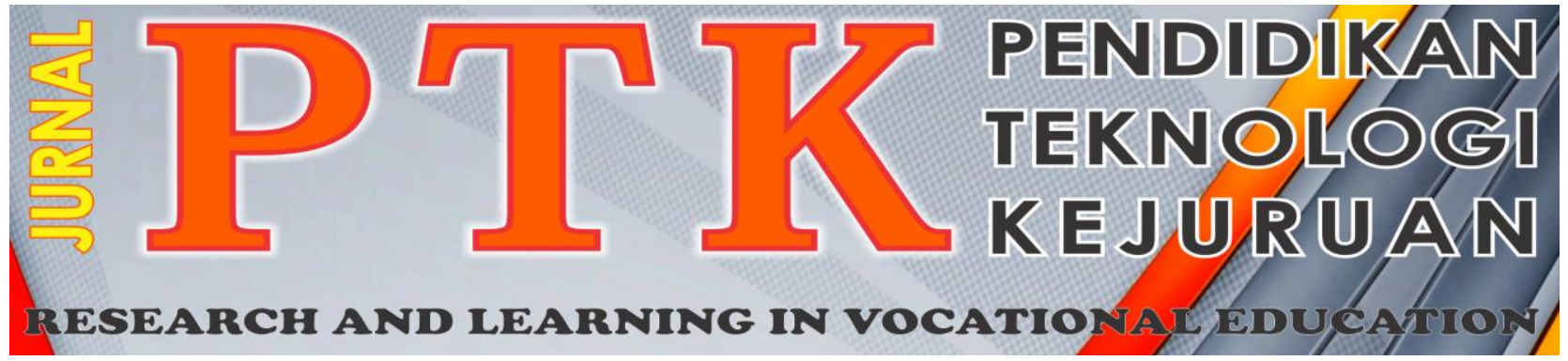

Vol. 1, No. 42018

P-ISSN: 2621-3273

E-ISSN: 2621-1548

\title{
Pengaruh Pengawasan Supervisor di Room Division terhadap Kinerja Karyawan Hotel Axana Padang
}

\author{
Murtia Arman', Kasmita ${ }^{2}$ \\ ${ }^{1}$ Prodi Pariwisata, Fakultas Pariwisata dan Perhotelan, Universitas Negeri Padang \\ ${ }^{2}$ Program Studi D4 Manajemen Perhotelan, Fakultas Pariwisata dan Perhotelan, Universitas Negeri Padang \\ *e-mail: murtiaarman08@gmail.com ${ }^{1}$
}

\begin{abstract}
Abstrak- penelitian ini bertujuan untuk mengetahui pengaruh pengawasan supervisor di room division terhadap kinerja karyawan hotel axana padang. Jenis penelitian ini adalah deskriptif kuantitatif dengan metode assossiatif kausal. Sampel diambil dengan menggunakan teknik sampling jenuh dengan jumlah 40 orang. Berdasarkan penelitian yang telah dilakukan maka didapatkan hasil sebagai berikut: (1) pengawasn supervisor berada pada kategori sangat baik (55\%), (2) kinerja karyawan berada pada kategori sangat baik (57\%), (3) hasil uji hipotesis regresi linear sederhana diperoleh $F \quad 1,003$ dengan sig. $0,000<0,05$, maka variabel pengawasan supervisor dapat menjelaskan variabel kinerja karyawan secara signifikan, dengan nilai $\mathbf{R}$ square sebesar 0,184 . Artinya pengawasan supervisor mempengaruhi kinerja karyawan sebesar 18,4\% dan 81,6\% dipengaruhi oleh faktor lain. Selanjutnya diperoleh t 2,925 dengan taraff signifikan $0,000<0,05$. Artinya setiap peningkatan sebesar 1 satuan pengawasan supervisor akan meningkatkan 0,190 satuan kinerja karyawan.
\end{abstract}

\section{Kata kunci: Pengawasan Supervisor, Kinerja Karyawan}

Abstract- This research is to find out the influence of Supervisory Supervision in Division Room on Employee Performance of Axana Hotel Padang. This type of research is quantitative descriptive with causal assumptions. using a sampling technique saturated with 40 people. Based on the research that has been done, the following results are obtained: (1) Supervisory Supervision remains in very good category (55\%), (2) Employee performance in the very good category (57\%) (3) The results of the simple linear regression hypothesis test are obtained $F 1.003$ with sig. 0,000<0,05, the supervisory supervisor variable can explain employee performance variables significantly, with $R$ Square value of 0,184. Supervisors monitored employee performance by $18.4 \%$ and $81.6 \%$ by other factors. Then obtained 2.925 with a significant level of $0.000<0.05$, then there is a significant relationship between the second variable. Then obtained the regression coefficient value of 0.190 with the value in the sig. $0,000<0,05$. This means that each increase of 1 supervisory supervisory unit will increase 0.190 employee performance units.

Keywords: Supervisor Supervision, Employee Performance

\section{Pendahuluan}

Pertumbuhan industri pariwisata Kota Padang mengalami kemajuan yang cukup pesat. Pertumbuhan industri pariwisata secara tidak langsung tidak terlepas dari aspek-aspek yang mendukungnya, salah satu sector pendukung industri pariwisata adalah jasa perhotelan. Hotel adalah Suatu perusahaan yang dikelola oleh pemiliknya dengan menyediakan pelayanan makanan, minuman, dan fasilitas kamar untuk tidur kepada orang-orang yang melakukan perjalanan dan mampu membayar dengan jumlah yang wajar sesuai dengan pelayanan yang diterima tanpa ada perjanjian khusus [1]. Salah satu divisi yang menyediakan penginapan untuk tamu di hotel adalah divisi kamar (room division).

Room division (divisi kamar) diartikan sebagai sebuah divisi di hotel yang terdiri dari gabungan departement dan fungsi memiliki peran penting dan bertanggung jawab terhadap penyediaan kebutuhan pemesanan kamar [2]. Devisi kamar juga memberikan pelayanan jasa kebersihan, perawatan, dan pemeliharaan kamar serta area-area umum di hotel, termasuk penyediaan pencucian pakaian serta pencucian dan pemeliharaan linen yang digunakan oleh departemen lain [3]. 
Supervisor adalah seorang manager pada tingkat bawah organisasi, yang harus mengawasi pengawasan junior [4]. Lebih lanjut tugas dan tanggung jawab supervisor meliputi: perencanaan, koordinasi, pengarahan, pengawasan dan evaluasi [4]. Salah satu tugas supervisor yaitu pengawasan, Pengawasan adalah suatu upaya sistematik untuk menetapkan kinerja standar pada perencanaan dan merancang system umpan balik informasi untuk membandingkan kinerja actual dengan standar yang telah ditentukan. Indikator pengawasan meliputi, "Pengawasan terhadap sumber daya manusia yang dipekerjakan, pengawasan terhadap material yang digunakan, pengawasan terhadap peralatan kerja, dan pengawasan terhadap system kerja [4].

Karyawan merupakan penggerak utama dari setiap organisasi. Tanpa mereka, organisasi dan sumber lainnya tidak akan menjadi suatu yang berarti [5]. Kinerja merupakan hasil yang dicapai oleh seorang karyawan dalam ukuran tertentu, berkenaan dengan pekerjaan serta perilaku dan tindakannya [5].

Hotel Axana Padang merupakan hotel berbintang empat (****) dan cukup berkembang yang berada di kota Padang. Berdasarkan pra penelitian pada tanggal 21 April 2018 dengan supervisor dan 2 orang karyawan peneliti mendapati berbagai masalah di bagian room division. Peneliti mewawancarai supervisor di room division terdapatnya permasalahan ketikan penjualan kamar yang tidak ada di konfirmasikan oleh front office department ke housekeeping department bahwa kamarnya sudah terjadi reservasi. Jadi dari housekeeping department belum menyiapkan kamar yang sudah melakukan registrasi dan ketika tamu mau di antar oleh bellboy kamarnya masih dalam proses dan tamu tersebut terpaksa menunggu di loby sampai kamarnya siap.

Berdasarkan hasil wawancara dengan karyawan masih terdapatnya jarangnya pengawasan yang dilakukan supervisor pada saat karyawan melakukan pengambilan dan penggunaan material pendukung pekerjaan yang tidak sesuai dengan jumlah yang dibutuhkan. Dari hasil observasi peneliti menemukan permasalahan yang berkaitan dengan pengawasan supervisor yaitu adanya pelaksanaan tugas dan tanggung jawab supervisor yang tidak dijalankan sesuai dengan tugas dan tanggung jawab yang semestinya. Hal ini dibuktikan dengan kurangnya pengawasan supervisor terhadap kebersihan area kerja, seperti yang yang peneliti dapati ruangan koridor masih didapati sampah tisu yang terdapat di kerpet koridor dan bekas trolly yang member jejak pada dinding koridor.

Peneliti juga mendapati informasi dari tripadvisor kurangnya pengawasan supervisor terhadap kamar yang sudah vacant cleant dengan adanya sisa air yang berdebu didalam ketel air. Ditemukan kecoa dikamar tamu, kondisi toilet yang tersumbat, serta mesin pendingin ruangan yang kurang dingin. Selanjutnya peneliti juga mendapatkan keluhan tamu terhadap kondisi kamar. Peneliti menemukan adanya penurunan kinerja karyawan yang diduga disebabkan oleh kelalaian waktu penyelesaian pekerjaan oleh karyawan, dan ketika peneliti mengunjungi kamar vacant yang sudah siap dijual, masih terdapat sampah tisu di bath room.

Selanjutnya saat peneliti melakukan observasi, peneliti mengamati terdapat karyawan yang istirahat dan tidak bekerja di jam kerja yang ditentukan. Seperti yang peneliti dapati karyawan main game dekat tangga yang tidak ada cctv pada saat jam kerja dan juga ditemukan diantara karyawan yang berkunjung ke departemen lain yang tidak memiliki kepentingan dalam urusan pekerjaan pada saat jam kerja.

Masalah lain yang masih terkait dengan masalah kinerja karyawan, ditemukan beberapa masalah seperti pada front office departement terjadinya kesalahan penginputan status kamar kamar yang tidak sesuai. Bagian housekeeping departement terlambat menginfokan ke bagian front office departement kalau kamarnya sudah vacant clean inspected keterlambatan tersebut membuat kamar belum bisa disewakan. Kinerja karyawan yang tidak sesuai dengan waktu kerja yang sudah ditetapkan. Seperti karyawan room division masih banyak mengeuh tentang jam kerja yang tidak sesuai dengan ketetapan perusahaan, dan karyawan room divison shift pagi, masih banyak yang pulang jam 5 belum bisa pulang kalau kamar yang dihandle belum siap. Sehingga ketika karyawan tersebut mengerjakan pekerjaannya, proses finishing kurang rapi dan produk yang dihasilkan kurang bagus. Hal ini dikarenakan kerja yang terlalu buru-buru dan tidak berdasarkan atas kemauan sendiri.

Berdasarkan hal tersebut maka tujuan penelitian ini adalah untuk (1) Mendeskripsikan Pengawasan Supervisor di room division Hotel Axana Padang; (2) Mendeskripsikan Kinerja Karyawan di Hotel Axana Padang; (3) Menganalisis Pengaruh Pengawasan Supervisor di Room Division Terhadap Kinerja Karyawan Hotel Axana Padang. 


\section{Studi Pustaka}

\section{A. Kinerja}

Kinerja merupakan hasil pekerjaan yang mempunyai hubungan kuat dengan tujuan strategis organisasi kepuasan konsumen, dan memberikan kontribusi pada ekonomi". Kinerja tidak hanya dinyatakan sebagai hasil kerja, tetapi juga bagaimana proses kerja berlangsung [6].

\section{B. Karyawan}

Karyawan adalah penghasil kerja bagi perusahaan hal ini berarti karyawan merupakan salah satu hal yang sangat penting dalam mencapai tujuan dari suatu perusahaan.. Karyawan adalah orang-orang professional yang tidak mudah digantikan. Karena mengganti seseorang tenaga professional akan sangat merugikan baik dari segi financial, waktu dan energi". Selanjutnya Karyawan merupakan penggerak utama dari setiap organisasi, tanpa mereka organisasi dan sumber daya lainnya tidak akan pernah menjadi sesuatu yang berarti[5].

\section{Supervisor}

Supervisor diartikan sebagai seseorang manager tingkat bawah organisasi yang mengawasi pegawai junior atau lainnya, yang mereka ini tidak punya kewajiban untuk mengawasi[4]. Selanjutnya supervisor merupakan titik kontak antara suatu tingkat tinggi dengan tingkat yang lebih rendah, anggota manajemen dan antara anggota menajemen pada tingkat menejemen terendah dari pada anggota manajemen".

\section{Pengaruh Pengawasan Supervisor Room}

\section{Devision Terhadap Kinerja Karyawan}

Penelitian terdahulu dalam penelitian ini digunakan sebagai gambaran kerangka berfikir, bahan perbandingan serta acuan dalam menyelesaikan penelitian ini.Sehingga penulis mencantumkan penelitian terdahulu yang relevan mengenai pengawasan supervisor terhadap kinerja karyawan.

Penelitian ini yang dilakukan oleh riyani fitri lubis (2015) dengan judul pengaruh pengawasan terhadap kinerja karyawan pada usaha bengkel menurut ekonomi islam di kecamatan pasaman kabupaten pasaman barat. Dimana hasil penelitian ini menunjukan bahwa variabel pengawasan berpengaruh positif dan signifikan terhadap kinerja karyawan pada usaha bengkel di kecamatan pasaman kabupaten pasaman barat $80,9 \%$.

Penelitian ini yang dilakukan oleh Elly Nielwaty, Prihati dan Sulaiman Zuhdi (2017) dengan judul pengaruh pengawasan terhadap kinerja pegawai disperindag sub bidang pengawasan barang dan jasa provinsi riau. Dimana hasil penelitian menunjukkan bahwa pengawasan berpengaruh positif dan signifikan terhadap kinerja pegawai dengan nilai koefisien determinasi (r2) sebesar 0,932, artinya 93,2\% kinerja pegawai dipengaruhi oleh pengawasan.

\section{METODE}

Jenis penelitian adalah deskriptif kuantitatif dengan pendekatan assosiatif kausal. Populasi adalah seluruh karyawan housekeeping department dan front office department Hotel Axana Padang yang berjumlah 40 orang. Teknik pengambilan sampel adalah non probality sampling yang digunakan adalah sampling jenuh.

Jenis data penelitian ini adalah data primer dan data sekunder. Data primer diperoleh langsung dari responden dengan menyebarkan kuisioner diantaranya data pengawasan supervisor dan kinerja karyawan. Selanjutnya untuk data sekunder didapat secara tidak langsung berupa tabel jumlah karyawan Hotel Axana Padang dari human resources department. Pengolahan data penelitian ini menggunakan bantuan SPSS versi 16.00 sesuai dengan tata cara penulisan karya ilmiah.

\section{HASIL DAN PEMBAHASAN}

\section{A. Variabel Pengawasan Supervisor}

Variabel pengawasan supervisor yang terdiri dari 25 butir pertanyaan yang diberikan kepadan 40 responden yang telah di uji validitas dan realibilitasnya. Distribusi frekuensi untuk variabel pengawasan supervisor bisa dilihat pada tabel 1 berikut:

Tabel 1. Deskripsi Data Variabel Pengawasan Supervisor (X) $\mathrm{N}=40$

\begin{tabular}{llcc}
\hline Kategori & Rentang Skor & $\begin{array}{c}\text { Frekuen } \\
\text { si }\end{array}$ & $\begin{array}{c}\text { Persentase } \\
(\mathbf{\%})\end{array}$ \\
\hline Sangat Baik & $\mathbf{1 0 0 , 0 5}$ & $\mathbf{2 2}$ & $\mathbf{5 5}$ \\
\hline Baik & $83,35-<100,05$ & 18 & 45 \\
\hline Cukup & $66,65-<83,35$ & 0 & 0 \\
\hline Buruk & $49,95-<66,65$ & 0 & 0 \\
\hline Sangat Buruk & $<49,95$ & 0 & 0 \\
\hline \multicolumn{2}{c}{ Total } & $\mathbf{4 0}$ & $\mathbf{1 0 0}$
\end{tabular}

Berdasarkan tabel 1 dapat dikatakan bahwa pengawasan supervisor di Hotel Axana Padang sebanyak $55 \%$ responden menyatakan sangat baik dan $45 \%$ responden menyatakan baik.

\section{B. Variabel Kinerja karyawan $(Y)$}

Variabel kinerja karyawan yang terdiri dari 23 butir pernyataan yang diberikan kepada 40 
responden yang telah diuji validitas dan realibilitasnya. Distribusi frekuensi untuk variabel kinerja karyawan bisa dilihat pada tabel 2 berikut:

Tabel 2. Deskripsi Data Kinerja Karyawan

\begin{tabular}{llcc}
\hline Kategori & \multicolumn{1}{c}{ Rentang Skor } & $\begin{array}{c}\text { Frekuen } \\
\text { si }\end{array}$ & $\begin{array}{c}\text { Persentase } \\
(\mathbf{\%})\end{array}$ \\
\hline Sangat Baik & $\geq \mathbf{9 1 , 9 5}$ & $\mathbf{2 3}$ & $\mathbf{5 7 , 5}$ \\
\hline Baik & $76,65-<91,95$ & 17 & 42,5 \\
\hline Cukup & $61,35-<76,65$ & 0 & 0 \\
\hline Buruk & $46,05-<61,35$ & 0 & 0 \\
\hline $\begin{array}{l}\text { Sangat } \\
\text { Buruk }\end{array}$ & $<46,05$ & 0 & 0 \\
\hline \multicolumn{2}{c}{ Total } & $\mathbf{4 0}$ & $\mathbf{1 0 0}$ \\
\hline
\end{tabular}

Berdasarkan tabel di atas dapat dikatakan bahwa pengawasan terhadap kinerja karyawan di Hotel Axana Padang sebanyak 57,5\% responden menyatakan sangat baik, $42,5 \%$ responden menyatakan baik.

\section{Analisis Data}

\section{Uji Normalitas}

Signifikansi yang didapatkan untuk variabel pengawasan supervisor adalah 0.608 dan kinerja karyawan sebesar 0.836 lebih besar dari 0,05, sehingga dapat dikatakan bahwa data kedua variabel terdistribusi normal karena tarh signifikasi lebih besar dari 0,05 .

\section{Uji Homogenitas}

Signifikansi yang didapatkan untuk pengawasan supervisor sebesar 0.060 dengan taraf signifikasi > 0.05 . ini artinya nilai signifikasi data lebih besar dari taraf signifikasi, sehingga dapat diambil kesimpulan bahwa data berasal dari populasi yang mempunyai varian yang sama atau data bersifat homogen.

\section{Uji Linearitas}

Signifikansi yang didaptkan untuk pengawasan supervisor sebesar 0.491 dengan taraf signifikasi > 0.05 yang artinya hubungan linear secara signifikasi antara variabel Pengawasan supervisor (X) dan Kinerja Karyawan (Y).

\section{Pengujian Hipotesis}

Berdasarkan data di atas diperoleh nilai $\mathrm{R}$ square 0.184 artinya kontribusi variabel pengawasan supervisor terhadap kinerja karyawan sebesar $18.4 \%$ sedangkan $81.6 \%$ dipengaruhi faktor lainnya.

Tabel 3. Hasil Uji R Square Variabel X Terhadap Y Model Summary

\begin{tabular}{|c|c|c|c|c|}
\hline Model & $\mathrm{R}$ & R Square & $\begin{array}{l}\text { Adjusted R } \\
\text { Square }\end{array}$ & $\begin{array}{l}\text { Std. Error of the } \\
\text { Estimate }\end{array}$ \\
\hline 1 & $.429^{\mathrm{a}}$ & .184 & .162 & 2.91941 \\
\hline
\end{tabular}

Berdasarkan data di atas diperoleh nilai $\mathrm{F}$ hitung 8.554 dengan signifikansi $0.000<0.05$, artinya variabel pengawasan supervisor dapat menjelaskan variabel kinerja karyawan secara signifikan. Berdasarkan perhitungan yang diperoleh maka hipotesis pertamanya adalah Ho ditolak dan $\mathrm{Ha}$ diterima, dengan demikian pengawasan supervisor (X) memiliki pengaruh yang signifikanterhadap kinerja karyawan (Y).

Berdasarkan data di atas, diperoleh nilai t sebesar 2.925 dengan taraf signifikasi $0.000<0.05$, artinya variabel $\mathrm{X}$ menjelaskan variabel $\mathrm{Y}$ secara signifikan. Berdasarkan persamaan di atas diperoleh koefesien regresi sebesar 0.190 dengan nilai sig. $0.000<0.05$. artinya setiap peningkatan 1 satuan pengawasan supervisor akan meningkatkan 0.190 satuan kinerja karyawan.

\section{E. Pembahasan}

\section{Pengawasan Supervisor (X)}

Berdasarkan hasil penelitian dari 40 orang sampel, maka variabel pengawasan supervisor diperoleh 55\% kategori sangat baik. Kemudian pada indikator pengawasan terhadap sumber daya manusia $42,5 \%$ responden menyatakan baik, pada indikator pengawasan terhadap material yang digunakan $92,5 \%$ responden menyatakan sangat baik, untuk indikator pengawasan terhadap peralatan kerja 50\% responden manyatakan baik, dan pada indikator pengawasan terhadap sistem kerja 50\% responden menyatakan baik. Secara umum pengawasan supervisor Hotel Axana Padang sudah termasuk kategori baik.

Pengawasan adalah suatu upaya yang sistematis untuk menetapkan kinerja standar pada perencanaan, untuk merancang sistem umpan balik informasi, untuk membandingkan kinerja actual dengan standar yang telah ditentukan, untuk menetapkan apakah telah terjadi suatu penyimpangan dan mengukur signifikasi penyimpangan tersebut, serta untuk mengambil tindakan perbaikan yang diperlukan untuk menjamin semua bahwa sumber daya perusahaan telah digunakan seefektif dan seefesien mungkin guna mencapai tujuan perusahaan.

Supervisory level adalah tingkat terbawah jajaran menajemen yang menempatkan supervisor pada posisi strategis dan unik sebagai peraan tengah, julukan linking-pins atau penghubung jajaran elit menejemen dengan karyawan bawah merupakan hasil pencerminan peran tengahnya, dimana keberadaannya sangat penting penyampaian informasi den perintah manajemen kepada karyawan sekeligus penyampai aspirasi karyawan bawah kepada manajemen [4].

Berdasarkan hasil penelitian ini terbukti bahwa variabel pengawasan supervisor termasuk kedalam 
kategori baik karena telah mampu memberikan pengawasan yang baik kepada kinerja karyawan. Hal ini terbukti berdasarkan hasil penilaian karyawan terhadap variabel pengawasan supervisor secara keseluruhan memiliki skor 55\%. Meskipun demikian sebaiknya pihak manajemen hotel lebih meningkatkan pengawasan supervisor. Hal ini terbukti pada penilaian karyawan pada pengawasan supervisor terhadap sumberdaya manusia dan penggunaan peralatan kerja masih kategori cukup. Peningkatan dapat dilakukan dengan cara menambah ilmu tentang Job desk Supervisor dan sering mengikuti pelatihan yang diadakan dari hotel maupun dari luar hotel.

\section{Kinerja Karyawan (Y)}

Berdasarkan hasil penelitian dari 40 orang responden, maka variabel kinerja karyawan dapat dikategorikan sangat baik dengan persentase sebesar $57 \%$. Kemudian pada indikator kualitas $87,5 \%$ responden menyatakan sangat baik. Selanjutnya pada indikator kuantitas $50 \%$ responden menyatakan sangat baik, pada indikator ketepatan waktu $77,5 \%$ responden menyatakan sangat baik, untuk indikator efektivitas $77,5 \%$ reponden menyatakan sangat baik, dan pada indikator kemandirian $97,5 \%$ responden menyatakan baik. Artinya penilaian karyawan terhadap kinerja karyawan di Hotel Axana Padang menyatakan sangat baik.

Karyawan merupakan penggerak utama dari setiap organisasi. Tanpa mereka, organisasi dan sumber lainnya tidak akan menjadi suatu yang berarti [5]. Jadi untuk dapat mencapai tujuan yang ingin dicapai oleh suatu organisasi dibutuhkan karyawan yang memiliki kinerja yang baik, sehingga kepuasan konsumen dapat tercapai. Karyawan yang bekerja di room division ini sangat diharapkan bisa memberikan kinerja yang terbaik.

3. Pengaruh Pengawasan Supervisor di Room

Division Terhadap Kinerja Karyawan Hotel

Axana Padang

Berdasarkan hasil uji hipotesis yang digunakan untuk mengetahui pengaruh antara pengawasan supervisor terhadap kinerja karyawan di Hotel Axana Padang maka didapat hasil persamaan koefisien regresi sebesar 0,190 dengan nilai sig. $0,000<0,05$. Artinya setiap peningkatan sebesar 1 satuan pengawasan supervisor akan meningkatkan 0,190 satuan kinerja karyawan. Maka variabel pengawasan supervisor (X) secara signifikan berpengaruh terhadap variabel kinerja kerja $(\mathrm{Y})$.

Kemudian diperoleh $\mathrm{R}$ square 0.184 artinya pengaruh pengawasan supervisor $(\mathrm{X})$ terhadap kinerja karyawan (Y) sebesar 0.184 (18.4\%) , sedangkan $81.6 \%$ dipengaruhi oleh faktor lain: inisiatif kerja, penampilan, sikap organisasi, dan fasilitas kerja. Maka hipotesis yang diterima dalam penelitian ini adalah $\mathrm{Ha}$ diterima Ho ditolak. Terdapat empat faktor yang dapat mempengaruhi kinerja yaitu: 1) Pegawai, berkenaan dengan kemampuan dan kemauan dalam melaksanaan pekerjaan. 2) Pekerjaan, menyangkut desain pekerjaan, uraian pekerjaan dan sumber daya untuk melaksanakan pekerjaan. 3) Mekanisme kerja, mencakup system, prosedur pendelegasian dan serta pengendalian serta struktur organisasi. 4) Lingkungan kerja, meliputi faktor-faktor lokasi dan kondidi kerja, iklim organisasi dan komunikasi [7].

Pengawasan supervisor room division di Hotel Axana Padang berdasarkan hasil pernyataan responden sesuai dengan permasalahan yang ada pada idetifikasi masalah yaitu masih minimnya sebagian pengawasan kerja supervisor, dan berdasarkan hasil penelitian pengawasan supervisor berpengaruh terhadap kinerja karyawan karena merupakan salah satu faktor yang dapat meningkatkan kinerja kerja karyawan di Hotel Axana Padang, karena pada dasarnya Pengawasan supervisor yang baik akan meningkatkan kinerja kerja karyawan. Semakin tingginya pengawasan supervisor maka persentase untuk kinerja juga akan semakin meningkat sehingga harapan dari perusahaan juga akan terpenuhi dan tentunya pendapatan dari perusahaan akan ikut meningkat pula.

\section{KeSIMPULAN}

Pengawasan supervisor di Hotel Axana Padang menunjukkan secara keseluruhan dengan nilai persentase sebesar 55,\% termasuk kategori sangat baik. Kinerja karyawan di Hotel Axana Padang menunjukkan secara keseluruhan dengan nilai persentase sebesar 57\% termasuk kategori sangat baik. Terdapat pengaruh pengawasan supervisor terhadap kinerja karyawan di Hotel Axana Padang dengan nilai konstanta sebesar 78.952. koefesien regresi sebesar 0.190 dengan nilai t sebesar 2.925 pada sig. $0.000<0.05$. artinya setiap peningkatan sebesar 1 satuan pengawasan supervisor akan meningkatkan 0.190 satuan kinerja karyawan. Kemudian diperoleh nilai $\mathrm{R}$ square 0.184 artinya pengaruh pengawasan supervisor (X) terhadap kinerja karyawan (Y) adalah sebesar $18.4 \%$, sedangkan $81.6 \%$ dipengaruhi oleh faktor lain yang tidak diukur dalam penelitian ini 


\section{DAfTar Pustaka}

[1] Sulastiyono, Metode Penelitian Kuantitatif Kualitatif dan R\&D. Bandung. Bandung: Alfabeta, 2010.

[2] Al-Bataafi and W. HS., Housekeepin Departement: Floor \& Public Area Job Description \& Standard Operating Procedur. Bandung: Alfabeta, 2006.

[3] Chair, Pramudia, and I. Meirina, Hotel Room Division Management. JakartA: Kencana, 2017.

[4] Bartono and Ruffino, Hotel Supervision dan Uji Kompetensi untuk Pendidikan Pariwisata. Yogyakarta: Andi, 2010.

[5] Suwanto, Priansa, and D. J, Manajemen Sumber Daya Manusia Dalam Organisasi Publik \& Bisnis. Bandung: Alfabeta, 2011.
[6] Wibowo, Manajemen Kinerja (Edisi Ke 3). JakartA: Rajawali Press, 2012.

[7] A. Dharma, Manajemen Supervisi. JakartA: Raja Grafindo Persada, 2001.

\section{Biodata Penulis}

Murtia Arman, lahir di Kampung Ladang, 16 Agustus 1994. Mahasiswa Manajemen Perhotelan Fakultas Pariwisata dan Perhotelan Universitas Negeri Padang.

Kasmita, lahir di Pekan Baru, 24 september 1970. Staff pengajar di jurusan Pariwisata Fakultas Pariwisata dan Perhotelan Universitas Negeri Padang. 